\title{
Urinary excretion of aromatic acids by sheep given diets containing different amounts of protein and roughage
}

\author{
By A. K. MARTIN \\ Hannah Dairy Research Institute, Ayr \\ (Received I6 October 1968-Accepted I 5 fanuary 1969)
}

\begin{abstract}
I. The urinary excretions of total diethyl ether-soluble acids and total aromatic acids of three sheep given maintenance diets containing different proportions of hay, rolled oats and decorticated groundnut meal were determined.

2. When the sheep were given the diet containing $70 \%$ rolled oats the excretion of aromatic acids in the urine was less than that observed when the sheep were given diets high in roughage or protein concentrates.

3. The amounts of aromatic acids excreted in the urine were not related to the dietary intakes of crude protein, apparently digestible crude protein, crude fibre, lignin or cellulose.

4. The excretion of comparatively large amounts of aromatic acids in the urine of ruminants is discussed in relation to the smaller amounts normally excreted by non-ruminants. Possible reasons for the failure to observe any relationship between the amounts of aromatic acids excreted in the urine of the sheep and those constituents of the diets that were investigated are discussed and the nature of other precursors is suggested.
\end{abstract}

Ruminants are generally considered to excrete much larger quantities of aromatic acids in their urine than monogastric animals. For example, work in this laboratory (A. K. Martin, unpublished results) has shown that adult sheep maintained on grass of varying stages of maturity excreted between 5 and $25 \mathrm{~g}$ of hippuric acid per $24 \mathrm{~h}$; the quantity decreased as the maturity of the grass increased. Adult man, on a 'normal' dietary regime, excretes between $\mathrm{r} \cdot 0$ and $2.5 \mathrm{~g}$ hippuric acid per $24 \mathrm{~h}$ (Stein, Paladini, Hirs \& Moore, 1954).

Blaxter, Clapperton \& Martin (1966) summarized their findings on the urinary carbon, nitrogen and energy excretion of cattle and sheep given a wide range of diets. They pointed out that the large range in energy excretion per $g$ of nitrogen (from 9 to $40 \mathrm{kcal} / \mathrm{g} \mathrm{N}$ ) could be explained by the varying proportion of hippurate $\mathrm{N}$ in the total urinary $\mathrm{N}$. (The heat of combustion of hippuric acid in $\mathrm{kcal} / \mathrm{g} \mathrm{N}$ is $72 \cdot 3$ compared with values of 5.4 to 13.4 for the other major components of urinary N.) Also it was found that the ratio of energy to $\mathrm{N}$ in the urine increased significantly with increasing food intake, indicating an increased output of energy-rich and $\mathrm{N}$-poor compounds derived from dietary sources. The quantitative significance of dietary components of ruminant rations as precursors of urinary aromatic acids is not known. Work is in progress in this laboratory to determine the significance of a number of possible precursors of urinary aromatic acids. Fibre (Schiemann, Zelk \& Nehring, 1965), lignin (Pazur \& DeLong, 1948; Csonka, Phillips \& Jones, 1929) and the aromatic amino acids of dietary proteins (Scott, Ward \& Dawson, 1964; Patton \& Kesler, 1967) have been considered as possible precursors.

In the experiments now reported, diets containing different proportions of protein, 
crude fibre and lignin have been given to sheep and the outputs of urinary aromatic acids have been determined. No clear relationship was observed between the outputs of urinary aromatic acids and the intake of these dietary constituents.

\section{EXPERIMENTAL}

\section{Animals}

Three sheep were used, two of which were of the Hampshire breed (I and 2) and the third (3) was of the Kent breed. All were 3 -year-old wethers. During the experiment the weights varied slightly. Sheep I weighed between $5^{2 \cdot 6}$ and $56 \cdot 4 \mathrm{~kg}$, sheep 2 between $55^{\circ} 6$ and $59^{\circ} 7 \mathrm{~kg}$ and sheep 3 between $58 \cdot 2$ and $6 \mathrm{I}^{\circ} \cdot \mathrm{rgg}$.

Table I. Daily intakes ( $g$ ) of the dietary constituents on the four diets $\mathrm{H}, \mathrm{HO}, \mathrm{HN}$ and $\mathrm{HON}$

$\begin{array}{lccc}\text { Diet } & \text { Hay } & \begin{array}{c}\text { Rolled } \\ \text { oats }\end{array} & \begin{array}{c}\text { Decorticated } \\ \text { groundnut } \\ \text { meal }\end{array} \\ \text { H } & 730 & - & - \\ \text { HO } & 166 & 385 & - \\ \text { HN } & 302 & - & 276 \\ \text { HON } & 78 & \text { r83 } & 252\end{array}$

Diets

Four diets were given to each of the sheep. The same poor-quality hay was used in all the rations. Diet $\mathrm{H}$ consisted entirely of hay; diet $\mathrm{HO}$ was composed of $70 \%$ rolled oats and $30 \%$ hay; diet $\mathrm{HN}$ was composed of $52 \%$ hay and $48 \%$ solvent-extracted decorticated groundnut meal, and diet HON consisted of $5 \mathrm{I} \%$ of diet $\mathrm{HO}$ and $49 \%$ of solvent-extracted decorticated groundnut meal. The daily intakes of hay, rolled oats and decorticated groundnut meal are given in Table I. In diets $\mathrm{HN}$ and $\mathrm{HON} 5^{\circ} \%$ of the gross energy was supplied by decorticated groundnut meal.

From preliminary experiments in which the apparently digestible energy of the diets was determined, the metabolizable energy content of each diet was calculated (Blaxter et al. I966). The fasting metabolism of these sheep was known from other experiments and the quantity of each diet required to supply this amount of metabolizable energy was calculated.

Each sheep was maintained on each diet for a total of 4 weeks. During the final week of each feeding period, urine was collected by aspiration from a urine funnel attached to the sheep harness (Martin, I966) into a reservoir containing a mercuric chloridepotassium dichromate preservative (Martin, 1966). Daily collections of faeces were made during this week and daily weights of faeces and urine were recorded and samples were taken for analysis. The feeding sequences were: for sheep no. I, diets $\mathrm{H}$, HON, HN and HO; for sheep no. 2, diets HON, HN, H and HO; for sheep no. 3 , diets $\mathrm{HN}, \mathrm{HO}, \mathrm{H}$ and $\mathrm{HON}$. 
Foods

Analytical methods

The dry-matter contents of the foods were determined by drying them to constant weight at $105^{\circ}$, the $\mathrm{N}$ contents by Kjeldahl digestion followed by macro-distillation into boric acid and titration with standard acid, and the energy contents by combustion in an adiabatic bomb calorimeter. Lignin was determined by the method described by Waite, Johnston \& Armstrong ( 1964 ), cellulose by the method of Crampton \& Maynard (1938) and crude fibre by the standard method of the Association of Official Agricultural Chemists. The results of these analyses are recorded in Table 2.

Table 2. Crude protein $(N \times 6 \cdot 25)$, crude fibre, lignin and cellulose contents ( $\%$ of dry matter) of diets $H, H O, H N$ and $H O N$

$\begin{array}{lcccc}\text { Diet } & \begin{array}{c}\text { Crude } \\ \text { protein }\end{array} & \begin{array}{c}\text { Crude } \\ \text { fibre }\end{array} & \text { Lignin } & \text { Cellulose } \\ \text { H } & 8 \cdot 8 & 36 \cdot 3 & 8 \cdot 4 & 48 \cdot 3 \\ \text { HO } & 9 \cdot 2 & 20 \cdot 4 & 6 \cdot 0 & 3 \times 7 \\ \text { HN } & 29 \cdot 0 & 24.4 & 6 \cdot 2 & 3 \circ \cdot 7 \\ \text { HON } & 29 \cdot 8 & 15.9 & 4 \cdot 9 & 21 \cdot 7\end{array}$

\section{Faeces}

At the end of each collection period representative samples were taken from each of the daily collections of faeces. The samples were pooled, and a known weight of water was added to each pooled sample and the sample was homogenized. The $\mathrm{N}$ and drymatter contents of the homogenate were determined.

\section{Urine}

Urine was weighed and sampled every $24 \mathrm{~h}$ during collection periods. Two or three of the daily samples were analysed as described below to determine the total concentrations of diethyl ether-soluble acids, hippuric acid and free aromatic acids.

Total acids soluble in diethyl ether. These were estimated by pipetting 25 or $50 \mathrm{ml}$ of urine into a continuous extraction apparatus, adjusting the $\mathrm{pH}$ to between $\mathrm{I}$ and 2 with $6 \mathrm{~N}-\mathrm{HCl}$, adding $50 \mathrm{ml}$ saturated sodium chloride solution and extracting continuously for $24 \mathrm{~h}$ with diethyl ether. The solvent was removed under reduced pressure at room temperature in a rotary film evaporator. Care was taken to ensure that the vacuum was released as soon as the last traces of solvent were removed or losses of volatile acids occurred. These diethyl ether-soluble acids were dissolved in water and titrated to $\mathrm{pH} 7 \cdot 0$ with $0^{\circ} \mathrm{I} \mathrm{N}-\mathrm{NaOH}$ using an automatic titration apparatus. The results were expressed in terms of benzoic acid equivalent (BAE). However, this fraction contains aliphatic acids (e.g. succinic acid, oxalic acid), free phenolic acids (e.g. $p$-hydroxy-phenylacetic acid) and aromatic acids (e.g. benzoic acid, phenylacetic acid) and glycine-conjugated phenolic and aromatic acids.

Hippuric acid. This was determined by estimating the $\mathrm{N}$ content of the acids extracted from acidified urine with diethyl ether. Urine $(5 \mathrm{ml})$ was acidified with $6 \mathrm{~N}-\mathrm{HCl}$ in a continuous extraction apparatus connected to a $100 \mathrm{ml} \mathrm{Kjeldahl} \mathrm{flask}$ 
and extracted with diethyl ether for $6 \mathrm{~h}$. On completion of the extraction, the diethyl ether was removed under reduced pressure. Urea was removed from the extract with sodium hypobromite as described by Griffith (1926). Tests showed that urea was completely removed by this procedure. The flask was heated to remove bromine and water, cooled, and the Kjeldahl catalysts ( $50 \mathrm{mg}$ mercuric oxide and $4 \mathrm{~g}$ potassium sulphate) were added followed by $5 \mathrm{ml}$ of concentrated sulphuric acid. Heating was continued for $40 \mathrm{~min}$ after the digest cleared. The ammonia in the digests was determined colorimetrically by one of two methods. Either the indophenol-blue method of Tetlow \& Wilson (1964), slightly modified by Martin (1966), or the ninhydrin method of Jacobs $(1956,1960)$ was used. The indophenol-blue method suffers from the disadvantage that very precise adjustment of the strongly acid digest to $\mathrm{pH} 7 \cdot 0$ must be made before the colour can be developed; buffers cannot be used. The method of Jacobs $(1956,1960)$ is simpler in that the digest is only approximately neutralized at $0^{\circ}$ with $\mathrm{NaOH}$ and then brought to $\mathrm{pH} 5.0$ with citrate buffer. Standard solutions of ammonium sulphate containing the digestion catalysts were analysed with each set of samples to determine the conversion factors. Recoveries of standard ammonium sulphate, urea and glycine solutions taken through the Kjeldahl digestion and colour development procedures, and also of hippuric acid taken through the ether extraction and colour development procedures, varied between $99^{\circ}$ I and $103.6 \%$.

Acids soluble in light petroleum (boiling range $40-60^{\circ}$ ). Experiments with a series of pure acids showed that continuous extraction of aqueous solutions at $\mathrm{pH} \mathrm{I}-2$ with light petroleum for $24 \mathrm{~h}$ would completely extract benzoic acid and phenylacetic acid and its homologues, but not aromatic acids with hydroxyl groups substituted either in the benzene ring or in the aliphatic side chain. Glycine conjugates of aromatic or phenolic acids and aliphatic acids (oxalic, lactic, citric, succinic and 2-oxoglutaric) were also insoluble in light petroleum. The titratable acidity of these extracts was expressed in terms of benzoic acid equivalent (BAE).

All urine analyses were begun immediately on completion of the $24 \mathrm{~h}$ collection period.

\section{Statistical analysis}

Analyses of variance were carried out to determine the significance of differences in urinary excretion of the various acid fractions examined. When significant differences were found on analysis of variance, those means which were significantly different from other means at $P<0.05$ were identified by means of the test devised by Tukey and described by Snedecor (1956).

\section{RESULTS}

A complex mixture of acids is extracted from acidified urine by diethyl ether (see p. 391). Ruminants excrete benzoic acid almost entirely in the form of its glycine conjugate, hippuric acid (Gupta, 1932; Ringer, I91 I Magnus-Levy, 1907). However, this compound is unstable at the high $\mathrm{pH}(6-8)$ of normal ruminant urine and decomposes to yield benzoic acid and glycine. The only acids extracted from acidified urine by light petroleum (boiling range $40-60^{\circ}$ ) are benzoic acid and its homologues, so the acidity of this fraction was determined at the same time as the hippuric acid analysis. 
The total aromatic acid excretion has been taken to be the sum of the BAE in the light petroleum extract and that found as hippurate.

The mean results for the excretion of acids in each of the urine fractions examined when the sheep were given the four diets used in these experiments are presented in Table 3, together with the standard error of diet means derived from analysis of variance. Some hydrolysis of hippuric acid may have occurred since appreciable quantities of unconjugated aromatic acids (e.g. $25 \%$ of the total aromatic acids excreted by sheep given diet $\mathrm{H}$; see Table 3 ) were found in the light petroleum extracts of the urine samples. The diethyl ether fraction, as already noted, contains acids other than aromatic acids: only between $70 \%$ (diet $\mathrm{HN}$, Table 3 ) and $75 \%$ (diet HON, Table 3) of the diethyl ether-soluble acids were aromatic acids, which is in agreement with the findings of Nehring \& Zelk ( 1965 ), who reported that estimation of hippuric acid as the total titratable acidity of diethyl ether extracts of acidified ruminant urine resulted in pronounced overestimation of hippuric acid excretion.

Table 3. Excretion ( $g$ benzoic acid equivalent/24h) of diethyl ether-soluble acids, hippuric acid, free aromatic acids and total aromatic acids by sheep given diets $H, H O$, $H N$ and $H O N$

\begin{tabular}{|c|c|c|c|c|}
\hline Diet & $\begin{array}{l}\text { Diethyl } \\
\text { ether } \\
\text { soluble } \\
\text { acids }\end{array}$ & $\begin{array}{l}\text { Hippuric } \\
\text { acid* }\end{array}$ & $\begin{array}{c}\text { Free } \\
\text { aromatic } \\
\text { acidst }\end{array}$ & $\begin{array}{c}\text { Total } \\
\text { aromatic } \\
\text { acidsf }\end{array}$ \\
\hline $\mathrm{H}$ & $\begin{array}{c}7 \cdot 82 \\
(7 \cdot 44-8 \cdot 55)\end{array}$ & $\begin{array}{c}4 \cdot 26 \\
(3 \cdot 29-5 \cdot 58)\end{array}$ & $\begin{array}{c}I \cdot 4 I \\
(I \cdot I 3-I \cdot 85)\end{array}$ & $\begin{array}{c}5.67 \\
(5 \cdot 14-6 \cdot 7 r)\end{array}$ \\
\hline $\mathrm{HO}$ & $\begin{array}{c}3 \cdot 97 \\
(3 \cdot 17-4 \cdot 95)\end{array}$ & $\begin{array}{c}2 \cdot 49 \\
(x \cdot 84-3 \cdot 43)\end{array}$ & $\begin{array}{c}0.43 \\
\left(0.35^{-0.54}\right)\end{array}$ & $\begin{array}{c}2.92 \\
(2.19-3.97)\end{array}$ \\
\hline $\mathrm{HN}$ & $\begin{array}{c}9.95 \\
(9.52-10.40)\end{array}$ & $\begin{array}{c}6 \cdot 27 \\
(5 \cdot 39-7 \cdot 73)\end{array}$ & $\begin{array}{c}0.67 \\
(0.44-1.02)\end{array}$ & $\begin{array}{c}6 \cdot 94 \\
(5 \cdot 83-8 \cdot 27)\end{array}$ \\
\hline HON & $\begin{array}{c}8.83 \\
(5 \cdot 06-9 \cdot 53)\end{array}$ & $\begin{array}{c}5 \cdot 89 \\
(3 \cdot 64-6 \cdot 72)\end{array}$ & $\begin{array}{c}0.70 \\
(0.25-0.89)\end{array}$ & $\begin{array}{c}6.59 \\
(4.21-6.97)\end{array}$ \\
\hline $\begin{array}{l}\text { ror of diet means } \\
\text { residual mean }\end{array}$ & 0.31 & 0.65 & $0 \cdot 16$ & 0.63 \\
\hline etween means & $r \cdot 60$ & $3 \cdot 35$ & 0.80 & 3.25 \\
\hline
\end{tabular}

Standard error of diet means (based on residual mean square)

Differences between means required for significance at $P<0.05$

* Calculated from nitrogen (after removal of urea) content of diethyl ether extracts of acidified urine.

+ Calculated from the titratable acidity of light petroleum (boiling range $40-60^{\circ}$ ) extracts of urine.

$\ddagger$ The sum of BAE in hippurate and free aromatic acid fractions.

Analysis of variance of the results summarized in Table 3 showed that there were no significant differences between the three sheep in the amounts of urinary acids excreted in each of the fractions examined. There were significant between-ration differences for all the urinary fractions: for acids soluble in diethyl ether, $P<0.00 \mathrm{I}$; for hippuric acid, $0.01<P<0.05$; for acids soluble in light petroleum, $0.01<P<0.05$ and for total aromatic acids, $0.01<P<0.05$. The individual between-ration differences (significant at $P<0.05$ ) which were responsible for the significance of the analyses of variance were identified as described by Snedecor (1956). For all urine 
fractions other than the free aromatic acids significantly smaller quantities of acids were excreted by sheep offered diet HO compared to those consuming either diet HN or diet HON. Sheep offered diet $\mathrm{H}$ also excreted significantly smaller quantities of diethyl ether-soluble acids than sheep consuming either diet $\mathrm{HN}$ or HON. The difference between diet means required for significance $(P<0.05)$ is shown in Table 3 .

In Table 4 the excretion of total aromatic acids by the sheep on the different dietary treatments has been calculated as mg BAE excreted per $\mathrm{g}$ crude protein ingested, and also per $g$ of apparently digestible crude protein, crude fibre, lignin and cellulose ingested. The individual results obtained were subjected to analysis of variance. There were no significant differences between sheep, but for each dietary component considered significant differences were found between rations, namely, crude protein $0.01<P<0.05$, apparently digestible crude protein $0.001<P<0.01$, crude fibre

Table 4. Excretion (mg benzoic acid equivalent/g intake) of total aromatic acids per unit of crude protein, per unit of apparently digestible crude protein and per unit of crude fibre, lignin and cellulose by sheep given the different diets

(Mean values for three sheep with their ranges in parentheses)

\begin{tabular}{|c|c|c|c|c|c|}
\hline Diet & $\begin{array}{l}\text { Crude } \\
\text { protein }\end{array}$ & $\begin{array}{l}\text { Apparently } \\
\text { digestible } \\
\text { crude } \\
\text { protein }\end{array}$ & $\begin{array}{l}\text { Crude } \\
\text { fibre }\end{array}$ & Lignin & Cellulose \\
\hline $\mathbf{H}$ & $\begin{array}{c}88 \cdot x \\
(79 \cdot 9-104 \cdot 3)\end{array}$ & $\begin{array}{c}187 \cdot 8 \\
(155 \cdot 2-238 \cdot 5)\end{array}$ & $\begin{array}{c}21 \cdot 4 \\
(19 \cdot 4-25 \cdot 3)\end{array}$ & $\begin{array}{c}92 \cdot 5 \\
(83 \cdot 9-109 \cdot 5)\end{array}$ & $\begin{array}{c}16 \cdot I \\
(14 \cdot 6-19 \cdot 0)\end{array}$ \\
\hline HO & $\begin{array}{c}57 \cdot 3 \\
(42 \cdot 9-77 \cdot 9)\end{array}$ & $\begin{array}{c}89 \cdot 6 \\
(66 \cdot 7-112 \cdot 2)\end{array}$ & $\begin{array}{c}26 \cdot 0 \\
(19 \cdot 5-35 \cdot 4)\end{array}$ & $\begin{array}{c}89 \cdot 4 \\
(66 \cdot 9-121 \cdot 4)\end{array}$ & $\begin{array}{c}16 \cdot 7 \\
(12 \cdot 5-22 \cdot 7)\end{array}$ \\
\hline HN & $\begin{array}{c}41 \cdot 3 \\
(34 \cdot 7-49 \cdot 2)\end{array}$ & $\begin{array}{c}49 \cdot 6 \\
(40 \cdot 8-58 \cdot 8)\end{array}$ & $\begin{array}{c}49 \cdot 3 \\
(4 x \cdot 4-58 \cdot 7)\end{array}$ & $\begin{array}{c}193 \cdot 9 \\
(162 \cdot 9-23 I \cdot 0)\end{array}$ & $\begin{array}{c}39 \cdot I \\
(32 \cdot 8-46 \cdot 6)\end{array}$ \\
\hline HON & $\begin{array}{c}44 \cdot 2 \\
(42 \cdot 9-45 \cdot 5)\end{array}$ & $\begin{array}{c}50 \cdot 0 \\
(48 \cdot 3-5 \times \cdot 7)\end{array}$ & $\begin{array}{c}83 \cdot 0 \\
(80 \cdot 5-85 \cdot 4)\end{array}$ & $\begin{array}{c}271 \cdot 9 \\
(263 \cdot 9-279 \cdot 9)\end{array}$ & $\begin{array}{c}60 \cdot 7 \\
(58 \cdot 9-62 \cdot 5)\end{array}$ \\
\hline $\begin{array}{l}\text { Standard error of diet } \\
\text { means (based on residual } \\
\text { mean square) }\end{array}$ & $7 \cdot 4$ & 15.4 & $4 \cdot 5$ & $16 \cdot 9$ & $3 \cdot 3$ \\
\hline $\begin{array}{l}\text { Differences in means } \\
\text { required for significance } \\
\text { at } P<0.05\end{array}$ & $38 \cdot 5$ & $79^{\circ} 9$ & 23.4 & $87 \cdot 3$ & 17.0 \\
\hline \multicolumn{6}{|c|}{$\begin{array}{l}P<0.00 \mathrm{I} \text {, lignin } 0.00 \mathrm{I}<P<0.0 \mathrm{I} \text { and cellulose } P<0.00 \mathrm{I} \text {. The difference } \\
\text { between means required for significance at } P<0.05 \text { is recorded in Table } 4 \text {. The } \\
\text { existence of these significant differences suggests that none of the food components } \\
\text { considered acts as the major precursor of the aromatic acids excreted. The ratio of BAE } \\
\text { excretion to crude protein consumption was significantly greater for diet } \mathrm{H} \text { than for } \\
\text { either diet HN or HON. When apparently digestible crude protein is considered, the } \\
\text { difference is even greater with diet } \mathrm{H} \text {, showing a significantly greater ratio than any } \\
\text { other diet offered. The between-diet ratios of the outputs of aromatic acids per unit } \\
\text { of crude fibre, lignin and cellulose were all similar. Thus, per unit of each of these } \\
\text { fractions, sheep given either diet HN or HON excreted significantly more BAE than } \\
\text { those given diet } \mathrm{H} \text { or, with the exception of crude fibre, diet HO. }\end{array}$} \\
\hline
\end{tabular}




\section{DISCUSSION}

In discussing the origin of the relatively large output of urinary aromatic acids by ruminants, a number of possibilities should be considered. These acids may arise as a consequence of the metabolism by rumen micro-organisms of precursors present in all foods; they may arise as a consequence of metabolism peculiar to ruminant tissues of precursors found in all foods; or they may arise from precursors peculiar to the diet of ruminants metabolized by either micro-organisms or the animal tissues.

Armstrong, Chao, Parker \& Wall (1955) found that the greater part of the hippuric acid excreted in the urine of man and the rat is derived from dietary sources. No information is available on the endogenous output of aromatic acids by ruminants but, assuming this to be small, the urinary excretion of benzoic acid by various species may be compared on the basis of their metabolic body sizes (i.e. body-weight raised to the power of 0.75 ; Kleiber, 1965). Thus, the results of Armstrong et al. (1955) indicate a range of from 14 to II $5 \mathrm{mg} \mathrm{BAE} / \mathrm{kgW}^{0775}$ per $24 \mathrm{~h}$ for man. Similar calculations for rats (Armstrong et al. 1955), rabbits (Chandler \& Lewis, 1932), dogs (Csonka et al. r929) and a chimpanzee (Power, I936) eating their normal diets give results that also fall within this range.

Table 5. Urinary excretion of aromatic acids by ruminants expressed as $m g$ benzoic acid equivalent $/ k g$ body-weight ${ }^{0.75}$ per $24 h$

\begin{tabular}{|c|c|c|c|}
\hline Animal & Diet & $\begin{array}{l}\text { Urinary } \\
\text { aromatic } \\
\text { acids }\end{array}$ & Reference \\
\hline Sheep & $\begin{array}{l}\text { Clover hay I } 46 \% \text { leaf } \\
\text { II } 34 \% \text { leaf } \\
\text { III } 24 \% \text { leaf } \\
\text { IV } 22 \% \text { leaf } \\
\text { V I } 8 \% \text { leaf }\end{array}$ & $\left.\begin{array}{l}715^{*} \\
569^{*} \\
445^{*} \\
385^{*} \\
364^{*}\end{array}\right\}$ & Pazur \& DeLong (1948) \\
\hline Dairy cows & $\begin{array}{ll}\text { Orchard grass I 'Pasture' (6-7 in. high) } \\
\text { Hay-grain } & \text { II 'Late pasture' ( } 8 \text { - - Io in. high) } \\
\text { Mixture } & \text { III Hay (10-12 in. high) } \\
& \text { IV Mature hay ( } 12-14 \text { in. high) }\end{array}$ & $\left.\begin{array}{r}756-1314^{*} \\
1087-1475^{*} \\
917-1153^{*} \\
578-983^{*}\end{array}\right\}$ & Ely et al. (1953) \\
\hline Cattle & $\begin{array}{l}\text { Various hays } \\
\text { Various straws } \\
\text { Silage }\end{array}$ & $\left.\begin{array}{l}677-965^{*} \\
516-615^{*} \\
93 \mathrm{I}-\mathrm{II} 6^{*}\end{array}\right\}$ & $\begin{array}{l}\text { Worth \& Gupta } \\
\left(193^{2}\right)\end{array}$ \\
\hline Sheep & $\begin{array}{l}\text { Hay }(\operatorname{diet} \mathrm{H}) \\
\text { Hay-rolled oats (diet HO) } \\
\text { Hay-groundnut meal (diet HN) } \\
\text { Hay-rolled oats-groundnut meal (diet HON) }\end{array}$ & $\begin{array}{l}235-326 \\
108-219 \\
266-406 \\
308-347\end{array}$ & $\begin{array}{l}\text { The experiments now } \\
\text { reported }\end{array}$ \\
\hline Deer & $\begin{array}{l}\text { Barley straw-maize starch-groundnut meal } \\
\text { Barley straw-maize starch-maize meal }\end{array}$ & $\left.\begin{array}{r}180-319 \\
96-127\end{array}\right\}$ & Topps et al. (1968) \\
\hline
\end{tabular}

* Body-weight of experimental animals not given. Sheep taken as $50 \mathrm{~kg}$ and cattle and dairy cows as $500 \mathrm{~kg}$.

When these values are compared with those given in Table 5 for ruminants, it is clear that the range for ruminants, though considerably affected by diet, is much larger than that normally found for non-ruminants. The values given in Table 5 have been calculated from the results now reported and from those obtained by other 
investigators. When sheep were given clover hays (Pazur \& DeLong, 1948) or cattle were given grass hays (Ely, Kane, Jacobson \& Moore, I953) of different maturities, the values obtained for the urinary excretion of aromatic acids appeared to be related to the maturity of the hays. The urinary excretion of aromatic acids was greatest when the dietary hay was made from grass cut at the stage of rapid stem elongation before the appearance of the inflorescence. The range in urinary aromatic acid excretion was from $1475 \mathrm{mg} \mathrm{BAE} / \mathrm{kgW}^{0.75}$ per $24 \mathrm{~h}$ for 'late pasture' (orchard grass hay made from grass 8-IO in. high cut before the 'hay' stage, Ely et al. 1953) to $235 \mathrm{mg} \mathrm{BAE/}$ $\mathrm{kgW}^{0.75}$ per $24 \mathrm{~h}$ for the poor-quality hay used (diet $\mathrm{H}$ ) in the experiments now reported. Incorporation of large amounts of cereal concentrates (rolled oats, maize meal) into diets resulted in the excretion of smaller quantities of urinary aromatic acids than when mature roughage was given: the excretion ranged between 96 and $219 \mathrm{mg} \mathrm{BAE} / \mathrm{kgW}^{0.75}$ per $24 \mathrm{~h}$ (Topps, Goodall, Kay \& Maloiy, 1968 and diet HO of the experiments now reported; see Table 5). However, inclusion of a protein concentrate (decorticated groundnut meal) in the ruminant diet led to a larger urinary excretion of aromatic acids than did cereal concentrates; between 180 and $406 \mathrm{mg}$ $\mathrm{BAE} / \mathrm{kgW}^{0.75}$ per $24 \mathrm{~h}$ were found (Topps et al. 1968 and diets $\mathrm{HN}$ and HON of these experiments; see Table 5). In the experiments reported here, although the addition of decorticated groundnut meal to the diet of hay and rolled oats (HO) resulted in a significant increase in total urinary aromatic acids, its addition to the diet of hay alone (H) did not cause a significant increase in the excretion of these acids in the urine. Although the difference was not statistically significant, two of the sheep did excrete larger amounts of total aromatic acids when the hay diet was supplemented by decorticated groundnut meal.

While inclusion of a protein concentrate in the ruminant diet was accompanied by an increase in the excretion of the total urinary aromatic acids (Table 3 ), this increase did not appear to be associated with the protein content of the concentrate (see Table 4). Scott et al. (1964) have shown that considerable conversion of phenylalanine into phenylacetic acid and of tyrosine into 3-phenylpropionic acid may occur in the rumen as a result of microbial fermentation. They found, however, that administration of radioactive phenylalanine into a sheep's rumen resulted in the excretion of only $0.2 \%$ of the activity as urinary diethyl ether-soluble acids (mainly phenylacetic acid) in a $6 \mathrm{~h}$ period after dosage. In a similar experiment, about $\mathrm{r} \%$ of the activity of tyrosine was recovered as urinary diethyl ether-soluble acids (mainly as benzoic acid) in an $8 \mathrm{~h}$ collection period. Scott et al. (1964) did not make collections of urine for $24 \mathrm{~h}$ periods after administration of radioactive amino acids, but for purposes of calculation it has been assumed here that the relative proportions of diethyl ether-soluble acids derived from amino acids were the same for a $24 \mathrm{~h}$ period as for the shorter periods (which may result in considerable overestimation). The amino acid intakes of the sheep given the rations used in the experiments now reported have been calculated from the data of Block \& Bolling (1945) on the amino acid composition of food proteins. When the urinary aromatic acids calculated to be derived from phenylalanine and tyrosine were expressed as percentages of the total amounts of benzoic acid excreted in the urine of sheep on each dietary treatment the following values were obtained: $1 \cdot 6$ 
for diet $\mathrm{H}, 2 \cdot 4$ for $\operatorname{diet} \mathrm{HO}, 3^{\circ} \circ$ for $\operatorname{diet} \mathrm{HN}$ and $2 \cdot 9$ for $\operatorname{diet} \mathrm{HON}$. Thus, ruminal fermentation of aromatic amino acids would seem to account for only a small proportion of the observed urinary output of aromatic acids.

None of the cellulose, crude fibre or lignin intakes of sheep was related to urinary aromatic acid output. Pazur \& DeLong (I948) have suggested that the lignin content of ruminant fodders may contribute to the urinary excretion of aromatic acids but Ely et al. (1953) were unable to demonstrate any relationship between the intake of apparently digestible lignin by dairy cows and their urinary excretion of aromatic acids. Both these groups of workers have reported that as the maturity of forages given to ruminants increased, and hence their intake of cellulose, crude fibre and lignin also increased, their urinary excretion of aromatic acids decreased. These findings support those of the present experiments in that they do not suggest that cellulose, crude fibre or lignin are major precursors of the urinary aromatic acids of ruminants. Lignin is a very complex polymer of variously substituted phenylpropane units (Freudenberg, I965) and in mature forages it is the most abundant aromatic compound. Its digestibility may be as high as $23 \%$ in young leafy forages but falls to zero in mature herbage (Waite et al. 1964). The diets used in the present experiments were all derived from mature plants, so the digestibility of the lignin was probably small but it was not determined. Recently, Higuchi, Ito \& Kawamura (I967) have reported that grass lignins are apparently unique amongst lignins so far investigated in having small amounts of phenolic acids linked to the body of the polymeric molecule by chemically labile ester linkages. These workers, investigating lignins from various mature Japanese grasses, found that from $2 \cdot 7$ to $6.1 \%$ of $p$-coumaric and from $r \cdot 3$ to $2 \cdot 9 \%$ of ferulic acids were combined in this manner. It is not known if these acids are liberated during digestion in the rumen, but, if they are, a substantial proportion of the urinary aromatic acids could arise from this source. The results of Higuchi et al. (r967) have been used to estimate the maximum possible contribution to urinary benzoic acid excretion of these labile phenolic acids in the lignin of the hay portion of the diets used in the present experiments. Thus, the proportion of the total urinary benzoic acid derivable from these groups has been calculated to be $5 \circ, 25,20$ and $5 \%$ for diets $\mathrm{H}, \mathrm{HO}, \mathrm{HN}$ and $\mathrm{HON}$, respectively. It is known that the lignin molecule loses methoxyl groups from the aromatic ring (Porter, 1965; Ely et al. 1953) and that the unsaturated aliphatic side-chain becomes saturated (Bondi \& Meyer, I943) during ruminant digestion.

It would appear that, while lignin may contribute towards the urinary BAE of ruminants, other dietary precursors must be present, which may be metabolized to aromatic acids either by rumen micro-organisms or by enzyme systems in the body tissues. In this respect Bernard, Vuilleumier \& Brubacher (1955) have shown that over $60 \%$ of the urinary aromatic acids excreted by guinea-pigs given hay were derived from water-soluble precursors in the hay. Similar results have been reported by Brigl \& Pfähler (I 929), who considered unidentified 'prolignins' to be responsible for $80 \%$ of the urinary aromatic acids excreted by rabbits given a hay diet. Amongst the precursors of lignin that are known to accumulate in plants are quinic acid and various cinnamic acid derivatives (Neisch, I964). Vasiliu, Timosencu, Zaimov \& 
Coteleu (1938) have shown that the urinary excretion of hippuric acid by sheep increased on giving oral doses of quinic acid, the increase being equivalent to $54 \%$ of the theoretical maximum that could be derived from quinic acid. It is possible that these compounds may be responsible for a large part of the urinary aromatic acids excreted by ruminants. In this respect, it may be noted that it has been shown that man, subsisting on an all-vegetarian diet of sweet potato, may excrete between 143 and $225 \mathrm{mg} \mathrm{BAE} / \mathrm{kgW}^{075}$ per $24 \mathrm{~h}$ (Luyken, Luyken-Koning \& Pikaar, 1964). Mosonyi, Oblatt \& Surjan (1948) successfully attempted to increase the urinary hippuric acid output of man from normal levels to as high as $2500 \mathrm{mg} \mathrm{BAE} / \mathrm{kgW}^{075}$ per $24 \mathrm{~h}$ on a diet of potatoes, oat flake, vegetable and prunes. Large amounts of quinic acid would be present in the diets used in the experiments of Mosonyi et al. (1948) and it has been shown that oral doses of quinic acid can be metabolized to hippuric acid by man (Adamson, Bridges \& Williams, I966). However, it is probable that the bacterial flora in the intestinal tract of man may be responsible for this aromatization (Asatoor, 1965).

The author is grateful for discussions with his colleagues and, in particular, for the advice and encouragement provided by Dr J. H. Moore. The experimental animals were in the care of $\mathrm{Mr} \mathrm{J}$. McDill and skilled analytical assistance was rendered by Miss R. Geddes and Miss J. T. Begg.

\section{REFERENCES}

Adamson, R. H., Bridges, J. W. \& Williams, R. T. (г966). Biochem. F. roo, 7 I P.

Armstrong, M. D., Chao, F. C., Parker, V. J. \& Wall, P. E. (1955). Proc. Soc. exp. Biol. Med. go, 675. Asatoor, A. M. (1965), Biochim. biophys. Acta roo, 290.

Bernard, K., Vuilleumier, J. P. \& Brubacher, G. (I955). Helv. chim. acta 38, 1438.

Blaxter, K. L., Clapperton, J. L. \& Martin, A. K. (I966). Br. F. Nutr. 20, 449.

Block, R. J. \& Bolling, D. ( I 945). The Amino Acid Composition of Proteins and Foods, ist ed. Springfield, Illinois: C. C. Thomas.

Bondi, A. H. \& Meyer, H. (1943). F. agric. Sci., Camb. 33, 123.

Brigl, P. \& Pfähler, A. (1929). Tierernährung I, 30 .

Chandler, J. P. \& Lewis, H. B. (1932). F. biol. Chem. 96, 6 I 9.

Crampton, E. W. \& Maynard, L. A. (1938). $\mathscr{7}$. Nutr. 15, 383 .

Csonka, F. A., Phillips, M. \& Jones, D. B. (1929). F. biol. Chem. 85, 65.

Ely, R. E., Kane, E. A., Jacobson, W. C. \& Moore, L. A. (1953). F. Dairy Sci. 36, 346.

Freudenberg, K. (1965). Science, N.Y. 148, 595 .

Griffith, W. H. (1926). In Practical Physiological Chemistry, r2th ed., p. 854. [P. B. Hawk, B. L. Oser and W. H. Summerson, editors.] London: J. \&. A. Churchill.

Gupta, N. C. D. (1932). Indian F. vet. Sci. 2, 289.

Higuchi, T., Ito, Y. \& Kawamura, I. (1967). Phytochemistry 6, 875.

Jacobs, S. (1956). Analyst, Lond. 8r, 502.

Jacobs, S. (1960). Analyst, Lond. 85, 257.

Kleiber, M. (1965). In Energy Metabolism, p. 427. [K. L. Blaxter, editor.] London: Academic Press.

Luyken, R., Luyken-Koning, F. W. M. \& Pikaar, N. A. (1964). Am. F. clin. Nutr. r4, I3.

Magnus-Levy, A. (1907). Biochem. Z. 6, 502.

Martin, A. K. (1966). Br. $\mathcal{~}$. Nutr. 20, 325.

Mosonyi, L., Oblatt, E. \& Surjan, M. G. (1948). Hung. Acta med. I, I.

Nehring, K. \& Zelk, V. (1965). Arch. Tiernähr. 15, 25.

Neisch, A. C. (1964). In Biochemistry of Phenolic Compounds, p. 295. [J. H. Harbourne, editor] London: Academic Press.

Patton, S. \& Kesler, E. M. (1967). F. Dairy Sci. 50, 1505.

Pazur, J. H. \& DeLong, W. H. (1948). Scient. Agric. 28, 39.

Porter, R. (1965). Proc. Nutr. Soc. 24, vi. 
Power, F. W. (1936). Proc. Soc. exp. Biol. Med. 33, 598.

Ringer, A. J. (I91 I). F. biol. Chem. ro, 327.

Schiemann, R., Zelk, V. \& Nehring, K. (1965). Arch. Tierernähr. 15, 8 I.

Scott, T. W., Ward, P. F. V. \& Dawson, R. M. C. (1964). Biochem. F. 9o, I 2.

Snedecor, G. W. (1956). In Statistical Methods, 5th ed., p. 251. Ames, Iowa, USA: The Iowa State University Press.

Stein, W. H., Paladini, A. C., Hirs, C. H. W. \& Moore, S. (1954). F. Am. chem. Soc. 76, 2848.

Tetlow, J. A. \& Wilson, R. L. (1964). Analyst, Lond. 89, 453.

Topps, J. H., Goodall, E. D., Kay, R. N. B. \& Maloiy, G. M. O. (r968). Proc. Nutr. Soc. 27, 53 A.

Vasiliu, H., Timosencu, A., Zaimov, C. \& Coteleu, V. (1938). Bul. Fac. ști. agric. Chişinău 2, 56.

Waite, R., Johnston, M. J. \& Armstrong, D. G. (1964). F. agric. Sci., Camb. 62, 39 I.

Worth, F. J. \& Gupta, N. C. D. (1932). Indian F. vet Sci. 2, 281 . 